Omni-Akuatika, 14 (1): 28-35, 2018
ISSN: 1858-3873 print / 2476-9347 online
Research Article
journal homepage: http://ojs.omniakuatikanet

\title{
Economic Valuation of Marine Tourism in Small Island Using Travel Cost Method (Case Study: Untung Jawa Island, Indonesia)
}

\author{
Firman Zulpikar $^{1 *}$, Leo Alexander Tambunan ${ }^{2}$, Siti Rahmi Utami ${ }^{1}$, Warsono El Kiyat ${ }^{3}$ \\ ${ }^{1 *}$ Green Economy Department, Surya University, Indonesia \\ ${ }^{2}$ Technopreneurship Department, Surya University, Indonesia \\ ${ }^{3}$ Nutrition and Food Technology Department, Surya University, Indonesia \\ "Corresponding author: firman.zulfikar@surya.ac.id
}

Received 19 February 2018; Accepted 2 May 2018; Available online 21 May 2018

\begin{abstract}
Marine tourism activities in small islands have an important role in the development of Indonesia maritime sector. This study aimed to estimate the economic value of marine tourism activities in Untung Jawa Island. Individual Travel Cost Method (ITCM) was selected to analyze the level of tourism demand of Untung Jawa. Samples were taken from three different season visits are weekday, weekend, and national holidays. The results showed the factors that have effect on the level of tourist demand of Untung Jawa Island are travel cost, income, and distance to the location. The potential economic value of marine tourism Untung Jawa Island was IDR 68,505,101,600 with consumer surplus of IDR 397,592 per individual trip. This value is higher than the average of actual visitor expenditure which reached IDR 296,860 per individual trip. Tourism activity has a positive impact on economic conditions of local communities. The results of this study have provided useful information for sustainable management of marine resources.
\end{abstract}

Keywords: economic value, marine tourism, travel cost, small island

\section{Introduction}

Tourism is one of the important sectors for the economic future of Indonesia. Ministry of Tourism and Creative Economy of Indonesia (2014) reported that marine tourism has increased significantly in the last 3 years. Moreover, in 2020 tourism sector predicted will give the biggest contribution to National GDP. Indonesia has a great potential for marine tourism because this country has thousands of beautiful islands as the prominent tourism destinations.

Recently, the Indonesia government has set up 10 new tourist destinations as a priority development in the maritime sector. One of them is Seribu Islands in Jakarta province. Seribu Islands is composed of many small islands, one of them was Untung Jawa Island. This Island has a wide variety of natural resources such as mangrove, seagrass and sandy beaches for swimming and watersport activities. The number of visitors to Untung Jawa covers $44 \%$ of the total visitors to Seribu
Islands (CBS Seribu Islands District, 2014). In 2016, the number of tourists visiting the Untung Jawa Island reached over 172,300 people, mostly come from Jakarta and Tangerang. Tourists arrivals to this island increase more than 10 percent/year. In the coming years, this island is predicted to become one of the leading tourism destinations in Indonesia.

Tourism is one of the biggest and fastest growing sectors in the global economy and has significant environmental, cultural, social and economic effects, both positively and negatively (Marrocu et al., 2015; Ghulamrabbany et al., 2013). Furthermore, these positive impacts include job creation, improvement of people's income, investment, infrastructure development, environmental protection and cultural development of local communities (Hampton and Jeyacheya, 2015; Zaei and Zaei, 2013) Tourism can be a major tool for economic development but, if not properly planned it will have destructive effects on biodiversity and environments pressure especially in small island with a limited environmental carrying 
capacity (Kurniawan et al., 2016) . Therefore, a wide range of policy, regulatory, and management tools are needed to reduce pressures on small island ecosystems and to promote their sustainable tourism (Hampton and Jeyacheya, 2015). Numerous studies have calculated the value of beaches in different areas worldwide (Bauwer et al., 2017; Isaza et al., 2015), but the study of economic value on small islands still lacking. Economic valuation provides information to facilitate more objectives decision making on marine natural resources management, as a tool susceptible to make key contributions to biodiversity and ecosystem services protection (Laurans et al., 2013) and creating alternative income for local communities. This study aimed to quantify the potential economic value and benefits of marine tourism activity in Untung Jawa Island.

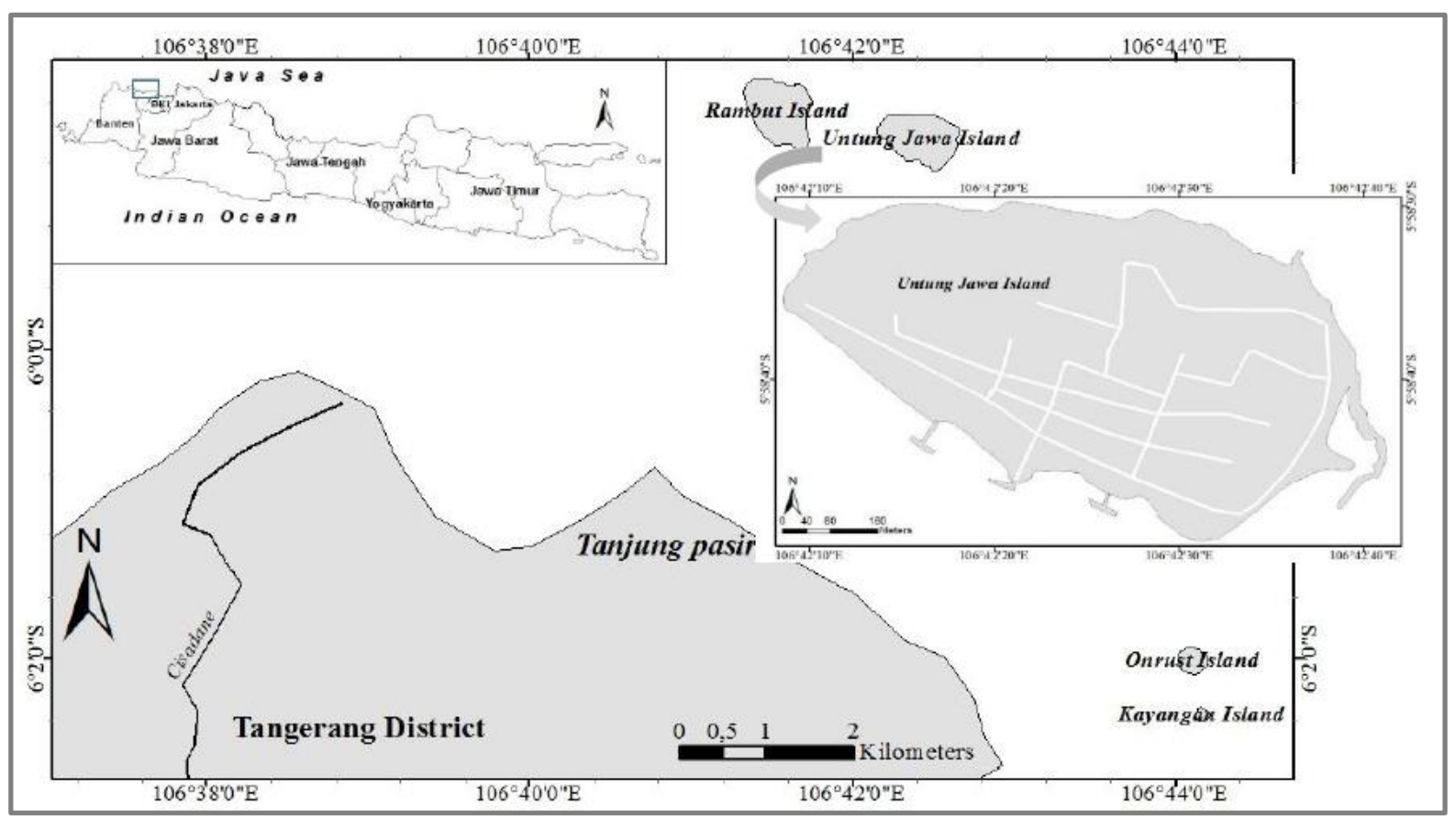

Figure 1. Map of Untung Jawa Island

\section{Materials and Methods}

\section{Study Area}

This study was conducted in Untung Jawa Island, located 10 miles from the west of Jakarta Bay (Figure 1). This island has the number of population of 2184 people with the area of 40.1 hectares and supported with adequate facilities and accessibility. Infrastructure such as roads, schools, clean water facilities, police stations and public health centers are well available. Tourist facilities such as homestays, toilets, restaurants, tourist information centers and leasing services have been growing quite rapidly along with the everincreasing number of tourists to the island.

Economic valuation conducted by using Individual Travel Cost Method (ITCM). This Method treats trips to a site as the quantity demanded, while the cost of the trip as the price of access to the site (Czajkowski et al., 2015). The travel cost method is commonly used to estimate the consumer surplus associated with traveling to the recreational sites such as parks, beaches, and heritage sites (Zhang et al., 2015). This method uses the calculation of the total expenditure of individuals to benefit from a tourism site. The desire for someone to visit a tourist site is also determined by several factors such as the cost of travel, monthly income, distance to the site (Czajkowski et al., 2015).

\section{Data collection}

A structured questionnaire was designed to obtain the trip data required to apply the individual TCM. The number of visitor sample in this study was determined by accidental quota sampling of 100 visitors. This technique applied to individuals who can meet accidentally when sampling performed. Respondents age limited minimum of 15 years. Data collected by direct interview with the visitors at the location. Surveys were conducted for three times from September to December, representing different 
seasons namely weekday, weekend, and national holidays.

Tourism demand to Untung Jawa Island measured with non-experimental quantitative approach. The dependent variable $(Y)$ used in this study was the number of trips (NT) to Untung Jawa Island undertaken from the respondents one year ago, whereas the independent variables $(X)$ were travel cost (including transportation, consumption, tickets, parking, and other expenses), average monthly income, distance to location, visitor age, gender, education level and duration of visit.

\section{Data analysis}

Data were analyzed by using regression analysis. A method used to analyze the relationship between variables. The relationship of these variables can be expressed in a regression equation as follows:

NT $=\alpha+\beta_{1}$ TC $+\beta_{2}$ INC $+\beta_{3}$ DIST $+\beta_{4}$ AGE $+\beta_{5}$
GEN $+\beta_{4}$ EDU $+\beta_{4}$ DUR

Where :

$\begin{array}{ll}\text { NT } & : \text { Number of Trips } \\ \text { TC } & : \text { Travel Cost } \\ \text { INC } & : \text { Income } \\ \text { DIST } & : \text { Distance } \\ \text { AGE } & : \text { Age of Respondens } \\ \text { GEN } & : \text { Gender } \\ \text { EDU } & : \text { Education Level } \\ \text { DUR } & : \text { Duration }\end{array}$

The potential economic value of marine tourism was determined by calculating the value of consumer surplus per trip. The value of consumer surplus were calculated according to Czajkowski et al. (2015) :

$\mathrm{CS}=\int_{p 0}^{p 1} f\left(P_{x}\right) d P$

Where $p 0$ is the lowest visitor expenditure, $p 1$ is the highest visitor expenditure and $P_{x}$ is the

cost of access to the site (which usually consists of the cost of travel and opportunity cost of travel time).

Potential economic value (PEV) of tourism then calculated by using the following formula :

PEV $=$ CS per trip $x$ number of visitors

\section{Results and Discussion}

\section{Characteristics of respondents}

Characteristics of respondents show socioeconomic characteristics of the visitors. All respondents in this study were domestic tourists. The descriptive statistics for dependent and independent variables are listed in Table 1. Travel cost variable was analyzed as continuous variable, other independent variables were analyzed as categorical variables.

Table 1. Descriptive statistics of respondents characteristics

\begin{tabular}{lcccc}
\hline \multirow{2}{*}{ Variable } & \multicolumn{4}{c}{ Sample $(n=100)$} \\
\cline { 2 - 5 } & Min/Minor & Max/Major & Mean & Std. Deviation \\
\hline Number of Visit (Trip/Year) & 1 & 7 & 1.97 & 1.23 \\
Gender (1 = Male, 2 =Female) & 1 & 2 & 1.39 & 0.49 \\
Age (Year) & 15 & 54 & 29.18 & 9.92 \\
Travel Cost (IDR) & 70,000 & 687,500 & 310,800 & $169,425.84$ \\
Distance (Km) & 60 & 240 & 91,5 & 41.20 \\
Monthly Income (IDR) & 500,000 & $15,000,000$ & $2,779,500$ & $2,312,636.51$ \\
Education (Total Year) & 6 & 18 & 12.2 & 2.74 \\
Duration (Day) & 1 & 2 & 1.29 & 0.45 \\
\hline
\end{tabular}

Table 2. Comparison of travel cost

\begin{tabular}{lccc}
\hline \multirow{2}{*}{ Tourism Season } & \multicolumn{3}{c}{ Travel Cost (IDR) } \\
\cline { 2 - 3 } & Minimum & Maximum & Average \\
Weekdays & 70,000 & 518,000 & 238,200 \\
Weekend & 80,000 & 535,000 & 316,500 \\
National Holiday Season & 125,000 & 560,000 & 326,125 \\
\hline
\end{tabular}


The result of interview indicated that majority of the visitors have been traveling to Untung Jawa Island at least 2 times in one last year. They come from various regions in Indonesia especially from Jakarta and Tangerang which is the closest area to the location. The visitors were dominated by young and productive women with the latest average education is senior high school. Jucan and Jucan (2013) have recently shown that Women worldwide have high involvement in tourism whether it is through being visitors, hosts or employees in the tourism destination sector. $49 \%$ of visitors work in private sector with monthly income ranging between $2-4$ million (IDR). Employment status has an influence on time availability and decision to travel. The visitors who work in private sector tend to choose travel time on the weekend and national holidays. Most of the visitors had a positive perception of the island, and more than $70 \%$ of visitors decided to come back in the future.

Untung Jawa is a single destination tourism. The visitors spent all their time and expenditures during the holidays in one location. In this research noted that most visitors only spend one day at the site. Travel cost to Untung Jawa Island was varied among visitors. This travel cost also depending on the season. The lowest cost of tourism is IDR 70,000 , spent by the visitor who comes to the site on weekdays while the highest travel cost of tourism is IDR 560,000 , spent by visitors who come on national holidays (Table 2). The difference in travel expenditure was due to the increase of tourism demand especially in peak season, this condition leads the increasing of goods and services prices at the location. Majority of visitors come to the island in July, August, and December. In general, travel expenditures on national holidays season are higher than on weekdays or weekends.

According to Marrocu et al. (2015), holiday timing has increased visitors expenditures due to higher prices applied in the high summer season. Thus, people who are traveling during the summer tend to spend more than people who are traveling in other seasons.

\section{Demand function of untung jawa tourism}

The demand function of tourism to Untung Jawa Island was determined by regression analysis. This function provides information regarding the relationship between travel cost and other variables regarding visitor decision to make a travel. Two types of econometric specifications were developed and tested in this study to estimate marine tourism demand models, namely Full Model, and TC Model. TC model assuming the travel cost as the only independent variable of the model. Full models, which include as independent variables are including the travel cost and other socioeconomic factors.

The results of regression analysis for the full model and TC model showed in Table 3 . In full model, the variables of travel cost, monthly income, and distance have significant effect on the number of trips (with 95\% confidence level), while variables of gender, education level, age, and duration had no significant value. Likewise with TC model, travel cost variable has a significant effect on the number of trips (with $95 \%$ confidence level).

Table 3. Results of regression analysis

\begin{tabular}{|c|c|c|c|c|c|c|c|c|}
\hline \multirow[b]{2}{*}{ Variable } & \multicolumn{4}{|c|}{ Full Model $^{* *}$} & \multicolumn{4}{|c|}{ TC Model } \\
\hline & Koef. & $\begin{array}{l}\text { Std. } \\
\text { Error }\end{array}$ & $\mathrm{t}$ & P-Value & Koef. & $\begin{array}{l}\text { Std. } \\
\text { Error }\end{array}$ & $\mathrm{t}$ & P-Value \\
\hline Intercept & 2,375 & ,317 & 7,489 &, $000^{*}$ & 3,042 & ,229 & 13,269 &, $000^{*}$ \\
\hline Travel Cost & $-2,87 E-6$ & ,000 & $-5,165$ &, $000^{*}$ & $-3,44 \mathrm{E}-6$ &, 000 & $-5,320$ &, $000^{*}$ \\
\hline Income & $1,77 \mathrm{E}-7$ &, 000 & 4,081 &, $000^{*}$ & & & & \\
\hline Distance &,- 007 & ,002 & $-3,619$ &, $000^{*}$ & & & & \\
\hline Gender &,- 164 & ,126 & $-1,304$ & ,195 & & & & \\
\hline Age &, 008 & ,007 & 1,124 & ,264 & & & & \\
\hline Education & ,014 & ,025 &, 543 & ,588 & & & & \\
\hline Duration & ,087 & ,148 & ,589 & ,557 & & & & \\
\hline $\mathrm{R}^{2}$ & ,446 & & & & ,224 & & & \\
\hline Sig. $F$ &, $000^{*}$ & & & &, $000^{*}$ & & & \\
\hline
\end{tabular}

\footnotetext{
* Significant with confidence level 95\%
}

** Selected model 
The estimated demand function can then be employed to estimate the visitor's consumer surplus or non-market value of the recreational site. Following on regression analysis, both full model and TC model can be expressed as follows:

\section{a. Full Model :}

$$
\begin{aligned}
\mathrm{NT}= & 2.375-0.0000028 \mathrm{TC}+0.00000017 \mathrm{INC}- \\
& 0.007 \mathrm{DIS}-0.16 \mathrm{GEN}+0.008 \mathrm{AGE}+0.014 \\
& \text { EDU + 0.08 DUR }
\end{aligned}
$$

b. TC Model :

$$
\text { NT }=3.042-0.0000034 \mathrm{TC}
$$

The coefficient of determination $\left(R^{2}\right)$ for full model and TC model was $44 \%$ and $22 \%$ respectively. Based on $\mathrm{R}^{2}$ value, it can be seen that the full model is better than the TC model. However, determination of the best model, not only determined by $\mathrm{R}^{2}$ value but also determined by other factors such as price elasticity.

Through analyzing the relationship between the travel costs (price) in accessing the recreational island site and the number of visits per year to this site (demand) for island visitors, a demand curve can be found.
Tourism demand curve mostly expressed on a linear model, semi-log model or double log model (Tourkolias et al., 2015). In This study, we choose a semi-log model to illustrate demand curve of Untung Jawa Island tourism as shown in Table 2. Based on the demand curve, the number of trips will decrease if travel cost increase. As the demand curve is decreasing, implies that the higher the cost, the fewer the visits (Zhang et al., 2015).

\section{Economic value estimation of Untung Jawa Tourism}

The potential of total economic value can be calculated with consumer surplus per trip multiplied by the total number of visitor in last year. The total number of visitors to Untung Jawa Island in 2016 have about 172,300 people. The bottom limit and upper limit of consumer surplus which calculated using the limited integral equation are IDR 70,000 and IDR 560,000 respectively. Two demand functions of TC model and full model were tested to estimate consumer surplus value. Table 4 showed the result of consumer surplus per trip and potential economic value of Untung Jawa Island tourism.

Table 4. Consumer surplus and potential economic value of Untung Jawa Island tourism

\begin{tabular}{cccccc}
\hline Model & $\begin{array}{c}\text { Consumer } \\
\text { Surplus } \\
\text { (IDR) }\end{array}$ & $\begin{array}{c}\text { Average Actual } \\
\text { Expenditure (IDR) }\end{array}$ & $\begin{array}{c}\text { Potential Economic } \\
\text { Value/Year (IDR) }\end{array}$ & $\begin{array}{c}\text { Actual Economic } \\
\text { Value/Year (IDR) }\end{array}$ & $\begin{array}{c}\text { Percentage } \\
(\%)\end{array}$ \\
\hline TC Model & 489,751 & 296,860 & $84,384,097,300$ & $51,148,978,000$ & 60.6 \\
Full Model & 397,592 & 296,860 & $68,505,101,600$ & $51,148,978,000$ & 74.6 \\
\hline
\end{tabular}

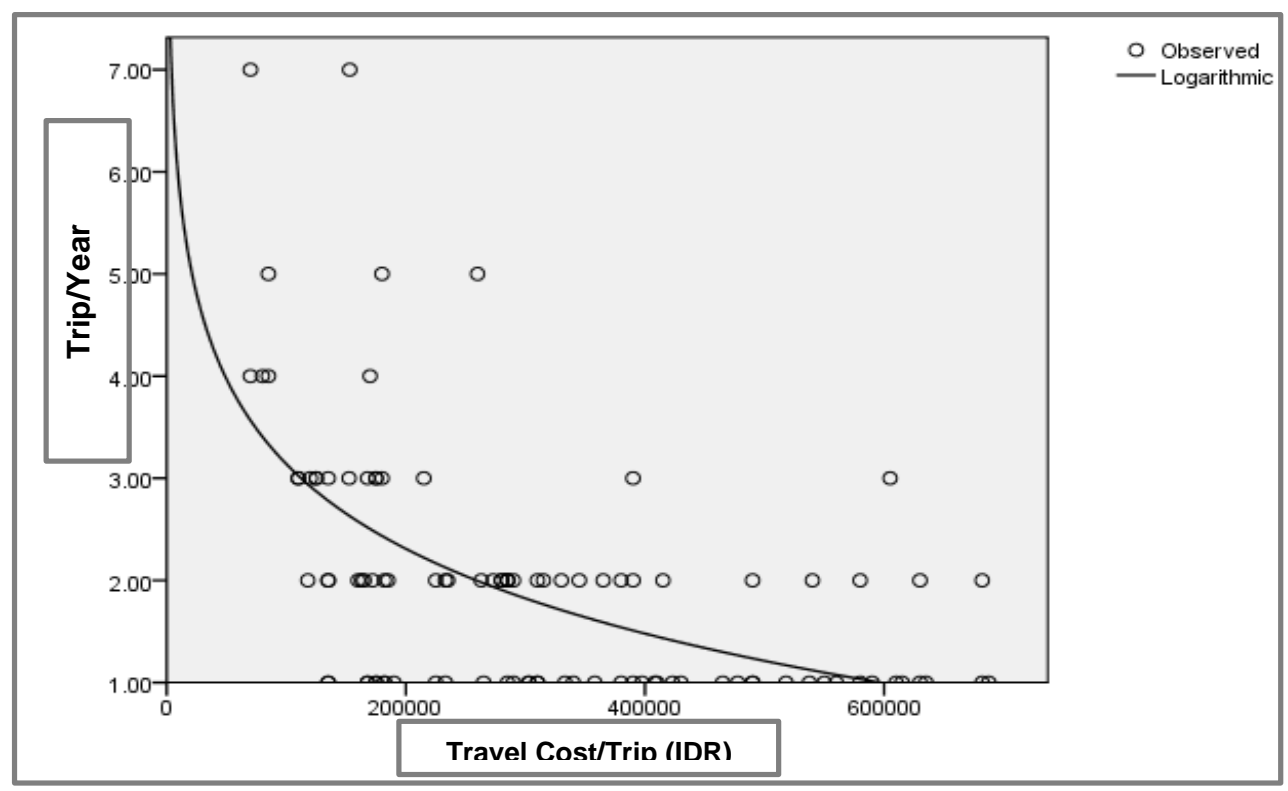

Figure 2. Demand curve of Untung Jawa tourism 


\section{Distribution of visitor expenditures}

Figure 2 showed that the highest expenditure (35\%) of visitors was allocated for consumption expenses (including food, drink, and beverages) during the location. The other high expenditures come from land transportation costs to a location that accounts for $22 \%$ of total expenditures. The operating costs of a car including fuel costs, toll tickets, tires and service/repairs. Other expenditures incurred by visitors included accommodation (10\%) and equipment rents (6\%) for snorkeling and watersport activities. Distribution of travel expenditures especially for accommodation (homestay) relatively low because most of the visitors only spend one day for a visit.

Results of expenditures analysis concluded that $64 \%$ of travel cost incurred onsite, while $36 \%$ of travel cost incurred from travel to site for land transportation and boat ticket. The proportion value of expenditure gave an overview that marine tourism in small island provides huge economic opportunities for local communities. They receive the largest portion of visitors expenditures. Therefore, the government receives a small portion of visitors expenditure sourced from parking tickets. Marrocu et al., (2015) stated that tourist expenditure makes a considerable contribution to economic growth at both the national and regional levels.

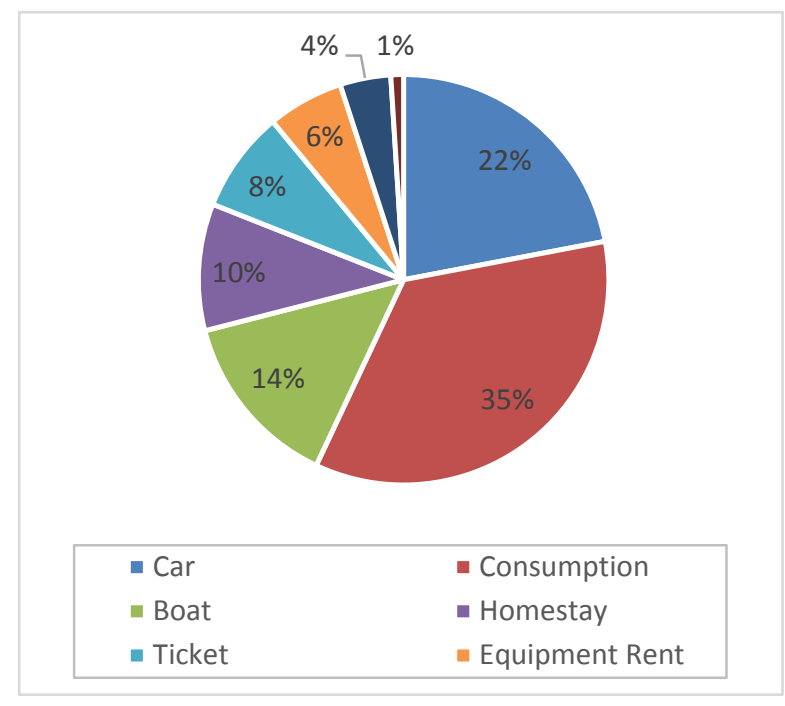

Figure 3. Distribution of visitor expenditures

Economic benefits of marine tourism to local communities

Marine tourism activities in Untung Jawa Island is an ideal example of sustainable natural resources located in small islands and managed directly by the local community. Natural resources in small islands are vulnerable to damage either by human activities or by nature (Kurniawan et al., 2016). However, if managed correctly, that resources can lead to increase local incomes and improve standards of living, and decrease dependence on less sustainable livelihoods such as fishing (Brauwer et al., 2017). In contrast, poor management can lead to conflict between resource users, severe habitat degradation, and leakage of revenue out of the local area (Job and Paesler 2013; Brauwer et al., 2017).

In the case of Untung Jawa tourism was known that local communities receive the direct economic benefit of $64 \%$ of total visitors expenditure. The direct economic benefits were derived from various products and services offered to tourists such as restaurants, homestay, rents, and others owned and managed directly by the communities. The number of tourism workers in Untung Jawa Island recorded about 552 people. Based on the calculation of the economic value proportion, the average monthly income of tourism workers reached to IDR $5,405,236$. This value is higher than the value of regional minimum wage (UMR) of Jakarta Province in 2017 which amounted to IDR 3,355,750 per month. To confirm the value of these economic benefits, random interviews were conducted with 10 tourism workers, the result shows that their monthly income ranges from IDR 5,000,000 - 6,000,000. Brauwer et al. (2017) founded the facts that local workers of marine tourism in Indonesia and Philippines 
receive a salary well above the national minimum wage.

Zaei and Zaei (2013) stated that tourism is an economic sector that can contribute significantly to economic growth and the labor market, as well as be creating direct and indirect employment through the provision of goods and services for tourism activities. Community involvement in planning activities and tourism management plays an important role in job creation and economic improvement of local communities (Honey, 2008).

The economic valuation technique offers substantive tools for policymakers to establish priority scales in decision making related to marine natural resource management (Pandeya et al., 2016). Understanding the recreational value of marine resources will help to support programs directly related to conservation and sustainable development issues.

\section{Conclusion}

Potential economic value of Untung Jawa Island tourism activities reached IDR $68,505,101,600$ per year with current utilization rate of $74 \%$. The tourism demands to Untung Jawa Island were influenced by the travel costs, distance and monthly income of visitor. Marine tourism sector plays an important role to improve economic income and job creation for local communities. The results of the research gave baseline information for sustainable management and development of marine tourism in small islands.

\section{Acknowledgement}

This research was funded by Directorate of Higher Education, Ministry for Research, Technology and Higher Education, Indonesia. The author would like to thank students of Department of Green Economy Surya University for kind supports.

\section{References}

Blackwell, B. 2007. The Value of a recreational beach visit: An application to Mooloolaba Beach and comparisons with other outdoor recreation sites. Economic Analysis \& Policy 37 (1): 77-98,

Brandã, C.N., Barbieri, J.C., Junior E.R. 2014. Analysis of the social, cultural, economic and environmental impacts of indigenous tourism: A multi-case study of indigenous communities in the Brazilian Amazon. Sustainable Tourism 187: 175 - 185.

Brauwer, M.D., Harvey, E.S., Mcllwaina, J.L., Hobbs, J.A. Jompa, J., Burton, M. 2017.
The economic contribution of the muck dive industry to tourism in Southeast Asia. Marine Policy 83: 92-99.

Central Bureau of Statistics, Seribu Islands District. 2014. Pariwisata Kabupaten Kepulauan Seribu. Kabupaten Kepulauan Seribu. ttp://kepulauanseribukab.bps.go.id/

Czajkowski, M., Giergiczny, M., Kronenberg, J., Englin, J. 2015. The individual travel cost method with consumer-specific values of travel time savings. Working Papers No.12. Faculty of Economic Sciences, University of Warsaw.

Ekonomou, G., Neofitou, C., Matsiori. S. 2013. Applying the travel cost approach for valuing recreation benefits of Fthiotida coastal zone. Journal of Environmental Science and Engineering 2: 389-397.

Godari, A. and Ghiyasi, S. 2014. Economic evaluation of Delfard Region by travel cost method. Journal Apply Environmental Biology Science 4 (3): 273277.

Hakim, A.R. 2011. Economic valuation of nature-based tourism object in Rawapening, Indonesia: An application of travel cost and contingent valuation method. Journal of Sustainable Development 4 (2): 91-101.

Hampton, M.P. and Jeyacheya, J. 2015. Power, ownership and tourism in small Islands: evidence from Indonesia. World Development 70: 481-495.

Honey, M. 2008. Ecotourism and Sustainable Development: Who Owns Paradise?. Washington, DC: Island Press.

Isaza, J.C., Rixcie, N., Brian, R., Winnie, W.Y.L. 2015. Valuing beaches to develop payment for ecosystem services schemes in Colombia's sea flower marine protected area. Ecosystem Services 11: 22-31.

Jaafar, M. and Maideen, S.A. 2012. Ecotourismrelated products and activities, and the economic sustainability of small and medium island Chalets. Tourism Management 33: 683-691.

Jala and Nandagiri, L. 2015. Evaluation of economic value of Pilikula Lake using travel cost and contingent valuation methods. Aquatic Procedia 4: 1315 1321.

Job, H. and Paesler, F. 2013. Links between nature-based tourism, protected areas, 
poverty alleviation and crises-the example of Wasini Island (Kenya). Journal Outdoor Recreation Tourism. 1-2: 18-28.

Kiper, T., Özdemir, G., Saglam, C. 2011. Environmental, socio-cultural and economical effects of ecotourism perceived by the local people in the Northwestern Turkey: Kiyiköy Case. Scientific Research and Essays 6 (19): 4009 - 4020 .

Laurans, Y., Rankovic, A., Mermet, L., Bille, R., Pirard, R., 2013. Actual use of ecosystem services valuation for decision-making: questioning a literature blindspot. Journal of Environmental Management 119: 208219.

Limaei, S.M., Ghesmati, H., Rashidi, R., Yamini, N. 2014. Economic evaluation of natural forest park using the travel cost method (Case study; Masouleh forest park, north of Iran). Journal of Forest Science 60 (6): 254-261.

Marrocu E., Paci, R., Zara, A. 2015. Microeconomic determinants of tourist expenditure: $A$ quantile regression approach. Tourism Management 50: 1330.

Pandeya, B., Buytaert, W., Zulkafli, Z. T.Karpouzoglou, T., Mao, F., Hannah, D.M. 2016. A comparative analysis of ecosystem services valuation approaches for application at the local scale and in data scarce regions. Ecosystem Services 22:250-259.

Pascoe, S., Doshi, A., Thébaud, O., Thomas, C.R. 2014. Estimating the potential impact of entry fees for marine parks on dive tourism in South East Asia. Marine Policy 47: 147-152.

Ramdas, M. and Mohamed, B. 2014. Impacts of tourism on environmental attributes, environmental literacy and willingness to pay: A conceptual and theoretical review. Procedia - Social and Behavioral Sciences 144: 378 - 391.

Tourkolias C., Skiada, T., Mirasgedis, S., Diakoulaki, D. 2015. Application of the travel cost method for the valuation of the Poseidon temple in Sounio, Greece.
Journal of Cultural Heritage 16(4): 567574.

Zaei, M.E. and Zaei, M.E. 2013. The impacts of tourism industry on host community. European Journal of Tourism Hospitality and Research 1 (2): $12-21$.

Zhang, F., Xiao, H.W., Paulo A.L.D., Chunbo, M. 2015. The recreational value of gold coast beaches, Australia: An application of the travel cost method. Ecosystem Services 11: 106-114.

Jucan, M.S. and Jucan, C.N. 2013. Gender Trends in Tourism Destination. Procedia Social and Behavioral Sciences 92: 437 444.

Kurniawan, F., Adrianto, L., Bengen, D.G., Prasetyo, L.B. 2016. Vulnerability assessment of small islands to tourism: The case of the marine tourism park of the Gili Matra Islands,Indonesia. Global Ecology and Conservation 6:308-326. 